\title{
Letter
}

Massimiliano Ferraresi*

\section{Political Budget Cycle, Tax Collection, and Yardstick Competition}

https://doi.org/10.1515/bejeap-2020-0380

Received November 2, 2020; accepted February 24, 2021

Abstract: This paper exploits the political cycle of Italian municipalities to test for the presence of strategic interactions in the collection of local taxation. The revenue from the personal income tax surcharge-a tax tool of low salience-is (positively) plagued by political manipulation and is found to be a strategic complement, but only when mayors run for re-election, a finding consistent with the yardstick competition hypothesis. More salient fiscal tools, such as property tax and user fees and charges, are also (negatively) affected by budget cycles, but they do not appear to be spatially correlated.

Keywords: spatial interactions, yardstick competition, political budget cycle, local taxation, tax salience

JEL Codes: H20, H71, H77

\section{Introduction}

The identification of strategic interactions among local governments has become one of the most hotly debated empirical issues, as the neighbours' dependent variable typically suffers from endogeneity problems. In the 'first generation' literature on fiscal competition (among others, see Case et al. 1993; Revelli 2003) neighbours' fiscal variables (taxes and expenditure) were instrumented by using all neighbours' (exogenous) variables, e.g. demographic

*Corresponding author: Massimiliano Ferraresi, European Commission, Joint Research Centre (JRC), Ispra, Italy, E-mail: massimiliano.ferraresi@ec.europa.eu 
characteristics. ${ }^{1}$ This approach has been criticized since the identification of causal interactions is far from straightforward (Gibbons and Overman 2012). Consequently, in the 'second generation' literature scholars have exploited quasi-natural experiments to analyse spatial interactions in fiscal decisions among local governments. However, this strategy has produced mixed results. On the one hand, Lyytikainen (2012), Isen (2014), and Baskaran (2014) find no evidence for tax mimicking in Finland, Ohio, and the West German state, respectively. On the other hand, Agrawal (2015) and Parchet (2019) find the presence of tax mimicking in United States and Swiss municipalities, respectively. Finally, Baskaran (2020) uses the reunification of Germany in 1991 to show that municipalities strategically interact when setting business tax, but only in the short term.

I elaborate on Ferraresi (2020), where a novel identification strategy to test for the presence of spatial interactions based on quasi-experimental evidence is applied, to complement that analysis along two dimensions. First, this work explicitly focuses on taxation, which, in contrast to spending decisions, is a more common policy choice in the yardstick competition literature. ${ }^{2}$ Second, it investigates whether and to what extent the salience of a tax influences the strategic incentives to manipulate fiscal policy decisions close to elections, which in turn might affect the presence of spatial interactions among municipalities.

More in detail, I use information on all Italian municipalities (except those in autonomous regions) in the period of 2001-2011 to exploit the exogenous variation in tax collection due to the political cycle. In this regard, I find that both salient and non-salient fiscal tools are affected by political manipulations close to elections, but intriguingly, the sign goes in opposite directions. ${ }^{3}$ While the revenue of more visible and salient tax instruments such as property tax and user fees and charges significantly decreases just before an election, the collection of the personal income tax surcharge (PIT) $-\mathrm{a}$ tax tool that is not very transparent-is found to be

\footnotetext{
1 An alternative strategy consists of relying on the maximum likelihood methodology, which requires additional assumptions on both the distributional and functional form. According to Allers and Elhrost (2005), 14 out of 19 empirical studies in their list used an instrumental variable approach, while only three adopted a maximum likelihood strategy. Moreover, among 14 studies conducted after the Allers and Elhrost review of the literature, 12 used an instrumental variable approach and two employed the maximum likelihood estimator.

2 There are quite a few papers focusing on yardstick competition in local taxation, and all of these rely on the standard spatial econometric approach (see, among the others, Bocci et al. 2019; Burger and Roger 2018; Padovano and Petrarca 2014; Revelli 2002).

3 To give a flavor of the tax salience, consider that according to a survey run by Censis (2011: p.11), ranking the taxes most hated by Italians, the local property tax (ICI) is in third position, while the national PIT is fifth. The PIT surcharge is not even mentioned in this ranking.
} 
higher in pre-electoral years as compared to other years of the term. I then use this result to induce variation in neighbouring municipalities' collection of revenue from these taxes. In particular, strategic interactions among local governments are identified using the fact that municipalities are surrounded by neighbours who are in different years of the political term. As long as the political cycle of neighbouring municipalities is not affected by the tax choice of a given municipality, it can be used as a valid instrument for the average tax collection of neighbouring local jurisdictions.

Following this approach, I find a positive and sizable presence of spatial interactions between municipalities for the PIT surcharge, while decisions on more salient taxes appear to be (weakly) not spatially correlated. Strikingly, what emerges therefore is that the collection of local revenues is a strategic complement, but only if the tax instrument is not salient. Further first-hand evidence suggests that strategic interactions are driven by municipalities guided by mayors who want to be re-elected in forthcoming elections: a finding consistent with the yardstick competition hypothesis.

The remainder of this article is structured as follows. Section 2 describes the institutional context and data. Section 3 presents the econometric strategy and discusses the empirical results. The last section offers some concluding remarks.

\section{Institutional Setting and Data}

The Italian Constitution defines four governmental administrative layers: the central government, regions, provinces, and municipalities. Municipalities are the smallest level of jurisdiction; there are around 8,000, and many of them (approximately 90\%) have fewer than 15,000 inhabitants.

Municipalities are responsible for various public functions such as social welfare services, territorial development, local transport, infant education, sports and cultural facilities, local police services, water delivery, waste disposal, as well as most infrastructural spending. Revenue for municipalities relies on transfers from upper levels of government (mainly central and regional governments) and, as a result of a lengthy process of fiscal devolution, on their own sources of revenue. As for the timing of policy decisions, every December the municipal government prepares a draft of the budget, a planning document that details both the total amount and distribution of the municipal expenditures in the year to come and how they will be financed. The budget is discussed in the council and must be approved by the end of the year.

In terms of a municipality's own revenues, the main municipal tax is a property tax due yearly by real estate owners to the municipality where the 
property is located and levied on both principal and other dwellings. However, this tax-and especially the principal dwellings component-has frequently been changed by the Italian government, even being replaced by compensating vertical transfers in the period of 2008-2011. Yet, from 1999 Italian municipalities have been able to raise an additional source of tax revenue through a surcharge on their residents' personal income tax (PIT), which is the most important national tax. In particular, the central government establishes lower and upper bounds on the PIT surcharge that municipalities can set, within the range of $0-0.5 \%$, although the upper-bound limit was raised to $0.8 \%$ percent in 2007. Moreover, since 2011 the central government has allowed municipalities not only to add exemptions but also to establish progressive tax rates applicable to income brackets independently set by municipalities. Finally, there are also various types of fees (for parking permits, occupation of public areas, use of billboards, and so on), and charges for the use of municipal services (infant schools, sports facilities, and so on).

Since 1993, the municipal-level electoral system in Italy has had a mayorcouncil system: the municipal council members and the mayor are separately and directly elected by citizens in elections normally held every five years during the period of April-June, but the timing is not the same for all municipalities. The staggering of electoral dates is the result of local governments having to resign before the end of their term because of the lack of a majority supporting the local government in the city council or because of political scandals or judicial impeachment. ${ }^{4}$ It is worth noting that in 2000 , the Italian municipal electoral system established a limit of no more than two consecutive mandates for the office of mayor.

The empirical analysis in this paper is based on a dataset for Italian municipalities resulting from a combination of different archives publicly available from the Italian Ministry of the Interior, the Italian Ministry of the Economy, and the Italian Institute of Statistics. It includes a full range of information organised into three sections: (1) municipal financial data; (2) electoral data covering the results of elections in which the mayors in office during the period covered by the dataset were elected; (3) municipal demographic and socio-economic data such as

4 In particular, the staggered timing of local elections is due to historical reasons. In fact, all the ruling war councils had to be replaced at the end of the Second World War in 1946. Although the replacement occurred at the same time for all cities, in the subsequent decades several municipalities (including Rome) faced government crises and new elections took place. Moreover, early terminations for other reasons-such as dissolution for suspected Mafia infiltration in the council, commissioner intervention, merging with other municipalities, violations of the law, and absence of candidates-changed the length of the term and the timing of elections. As a result, each city follows its own electoral cycle. Note that the staggered time of elections allows time effects and effects of the year of the term to be estimated separately (Sjahrir et al. 2013). 
population size, age structure, and average income of inhabitants. I restrict the sample to municipalities located in ordinary statute regions, and I do not include municipalities with missing values. Finally, I obtain a balanced panel sample of 5572 municipalities, including 61,292 observations from 2001 to 2011.

The main dependent variable is the per capita revenue from the PIT surcharge $(P I T) .{ }^{5}$ For robustness, a set of time-varying variables that characterize a municipality's demographic and economic situation is also included: population of the municipality ( $p o p$ ), the proportion of citizens aged between zero and five years (child), the proportion of citizens aged over 65 (aged), the per capita average income of the municipality (income), and transfers from higher levels of government (grants). A dummy variable accounting for whether (and when) a municipality was placed under a commissioner (commissioner) in the period of 2001-2011 is also included. ${ }^{6}$ Descriptive statistics are reported in Table A1 of the Online Appendix.

\section{Estimation Strategy and Results}

The classical model of spatial interactions can be written as follows:

$$
P I T_{i t}=\gamma^{\prime} W P I T_{i t}+\beta^{\prime} X_{i t}+\mu_{i}+\tau_{t}+\epsilon_{i t}
$$

where $P I T_{i t}$ is the per capita revenue from the PIT surcharge of municipality $i$ at time $t, W P I T_{i t}=\sum_{j \neq i} \omega_{i j} P I T_{j t}$ is the weighted per capita average revenue from the PIT

5 As discussed above, the modification of allowable tax rates over time, the introduction of exemptions, as well as the possibility of setting progressive tax rates applicable to income brackets are examples of changes that might undermine the possibility of a homogeneous comparison of tax rates across municipalities, thereby leading to some issues in the identification of spatial effects. Therefore, in order to properly compare municipalities' fiscal policies, I use revenues instead of tax rates. Nevertheless, to the end of reinforcing the analysis, I also collect information on the tax rate of the PIT surcharge, averaging multiple values when necessary (i.e. in the presence of multiple tax rates applicable to income brackets). Hence, I replicate the baseline specification by using the PIT tax rate as the dependent variable; reassuringly, results are very similar, pointing to the presence of tax mimicking among municipalities. This analysis is available upon request.

6 The municipal council can be dismissed by the Ministry of Interior and be replaced-for a given period-by a commissioner. According to Italian Law 267/2000, there are three main reasons for council dismissal: (a) Mafia infiltration, (b) resignation of officials, and (c) rejection of the annual budget. The commissioner is in charge of the overall governance and functioning of the municipality in which she intervenes, including decisions on the budget. Once the commissioner period finishes, there are local elections and the commissioner is then replaced by the elected mayor. 
of neighbouring municipalities $j$ at time $t ; \omega_{i j}$ are weights that aggregate the per capita revenue of neighbouring municipalities into a single variable $W P I T_{i t}$ and are normalized so that $\sum_{j \neq i} \omega_{i j}=1 .^{7}$ The vector $X_{i t}$ includes control variables described in Section 2, while $\mu_{i}$ and $\tau_{t}$ are municipal and year fixed effects. Robust standard errors are clustered at the municipal level.

As previously mentioned, the simultaneous determination of revenues makes the variable WPIT $_{i t}$ endogenous. To deal with this issue, I exploit the change in PIT revenues due to the political cycle, allowing municipality attributes $\mathrm{X}$, which are unlikely to be valid instruments, to be replaced by a variable that induces a continuous exogenous change in the average value of the revenue from the PIT surcharge collected by neighbours.

The key question is then whether Italian municipalities are affected by the political budget cycle. Figure 1 depicts the estimated coefficients of a model in which I use the per capita revenue from the PIT surcharge as the dependent variable and five dummy variables-one for each year of the term-as regressors, while controlling for both municipal and year fixed effects. Taking the election year as the baseline, the figure, although descriptive, suggests that the PIT surcharge increases as elections approach and drops just after elections, before continuing to rise again.

To rationalise this finding, it must be recognized that Italian municipalities are not allowed to run a deficit (Law 267/2000); therefore, any increase in the municipal expenditure, typically observed in pre-electoral years (Ferraresi et al. 2019; Repetto 2018), is to be financed by means of transfers and local taxes. ${ }^{8}$ As was already alluded to, there are taxes that are highly unpopular and very visible (property tax and user fees and charges), while the PIT surcharge is a less visible and less salient way to impose burdens on residents (Bordignon et al. 2017). It then follows that the political cost incurred by local administrators to leverage the PIT surcharge for the financing of pre-electoral expenditure hikes is much lower than the cost they would bear by increasing the property tax and/or fees and charges. Therefore, if the salience of the tax is at stake, one would expect the PIT surcharge

7 The approach used here involves only considering neighbours that are contiguous municipalities as this is a neutral and simple definition that captures the idea that interactions are more likely to take place between adjoining jurisdictions.

8 Transfers change proportionally with population size, area, population density, age composition, previous expenses, and the presence of a military base (Law 504/1992). The effective amount is determined in the annual budget law and approved by the parliament at the end of December. It then follows that officials do not have discretion in setting vertical transfers, and therefore, they are hardly to be manipulated (see the discussion in Section A2 of the Online Appendix). 


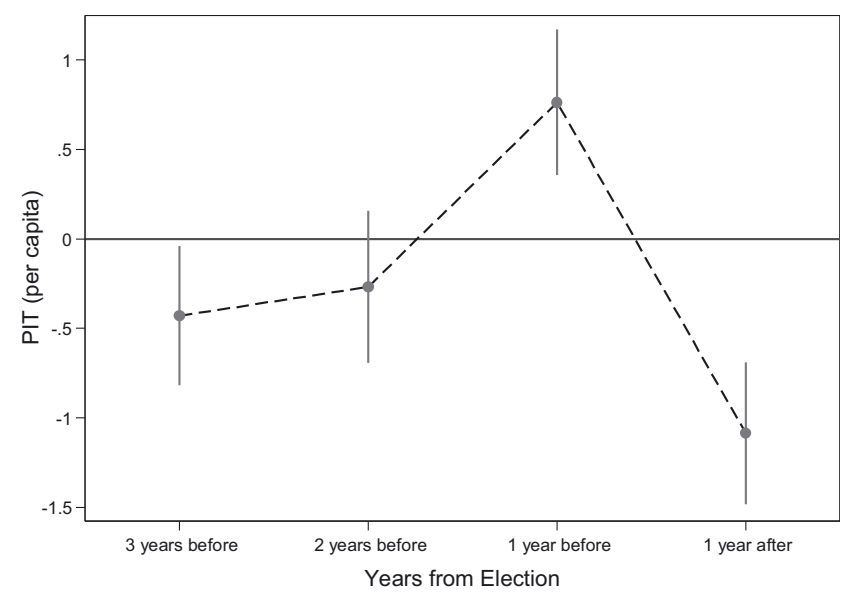

Figure 1: PIT surcharge and the political budget cycle. This graph is based on the estimates where I use PIT per capita surcharge as the dependent variable and four dummy variables indicating each year of the electoral term, controlling for municipal fixed effects and time dummies. Dots represent point estimates taking the election year as the baseline, while lines denote $95 \%$ confidence intervals.

to increase close to elections and the revenue associated with the property tax and user fees and charges to decrease over the same period. ${ }^{9}$

To test for this, I collected information on the property tax, levied on both principal and other dwellings (ICI), and user fees and charges (fees \& charges). ${ }^{10} \mathrm{I}$ then replicated the same approach used in Figure 1 by adopting the per capita revenue from the ICI and revenue from fees \& charges as the dependent variable, respectively. The results of this analysis are depicted in Figure 2. Consistent with my prediction, and taking the election year as the baseline, the figure suggests that

9 A similar argument can be found in Bracco et al. (2019), who state that politicians strategically rely more on less salient revenue sources as compared to less visible ones during electoral competitions.

10 It is worth noting that during the period of 2008-2011, the revenue from the ICI on principal dwellings was replaced by a compensating transfer from the central government, undermining its comparability over time. In addition, the distinction between revenue from property tax levied on owner-occupied dwellings and revenue from property tax levied on other dwellings is recorded in Italian municipal budgets only from 2006 onwards, whereas before 2006 there was just a unique item, 'revenue from property tax', registered in the balance sheets of Italian municipalities. As a consequence, the variable used in the analysis, ICI, contains the overall revenue from the property tax from 2001 to 2005, the sum of the revenues from the property tax levied on principal dwellings and on other dwellings from 2006 to 2007, and the revenue from the property tax levied on other dwellings from 2008 to 2011. 

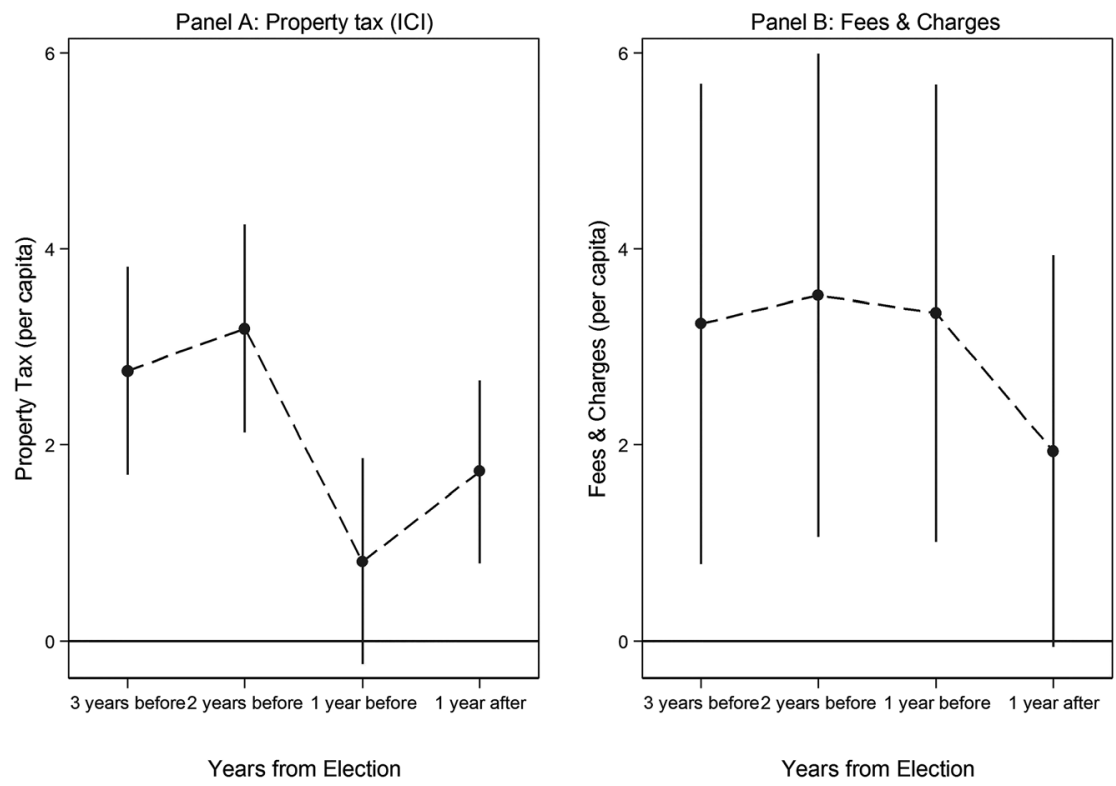

Figure 2: Property tax, fees \& charges, and the political budget cycle. This graph is based on the estimates where I use either the revenue from the per capita property tax (panel $A$ ) or from fees and charges (panel B) as the dependent variable and four dummy variables indicating each year of the electoral term, controlling for municipal fixed effects and time dummies. Dots represent point estimates taking the election year as the baseline, while lines denote $95 \%$ confidence intervals.

the revenue from ICI increases as elections approach and drops significantly just before elections (Panel A). A similar pattern, although much less marked, emerges also for the revenue from users' fees \& charges (Panel B).

Following Bracco (2018), I thus proxy the political budget cycle with a preelection dummy variable that takes the value of one in the year before the election and zero otherwise. ${ }^{11}$ Then, I construct an average for this dummy across neighbours to instrument $W I T_{i t}$, the per capita PIT of neighbouring municipalities. It follows that the first stage can be written as:

$$
W P I T_{i t}=\lambda W d_{i t}^{\tau-1}+\beta^{\prime} X_{i t}+\mu_{i}+\tau_{t}+\epsilon_{i t}
$$

where $W d_{i t}^{\tau-1}$ is the (average) pre-electoral year dummy variable across neighbours. ${ }^{12}$

11 It is also worth noting that the revenue from the PIT surcharge reaches its maximum in the preelectoral year compared to all other years of the term.

12 The pre-electoral year dummy variable $\left(d_{i t}^{\tau-1}\right)$ is also included in the first stage. 
The rationale behind this instrument is that the variation in neighbours' revenues from the PIT surcharge can be explained by the position of each neighbouring municipality in its own term, the intuition being that the collection of revenue is likely to be affected when municipalities are approaching electoral years. The validity of the instrument is based on the assumption that neighbours' political cycles are uncorrelated with the error term in Eq. (1). While this assumption is not directly testable, I argue that it is likely to hold since the instrument is based on the timing of elections in neighbouring municipalities, which from the municipality perspective can be reasonably considered as exogenous. After all, it is unlikely that a municipality deliberately manipulates the timing of elections in view of the tax collection of its neighbours.

The results in column 1 of Table 1 suggest that the instrument, i.e. neighbours 1 year before election, as expected, has a positive and highly significant effect on the weighted average of neighbour revenue from the PIT surcharge. Consistent with the statistical significance of the instruments in the first stage, the KleinbergenPaap F statistics reported at the bottom of the table show that the instrument is very strong (188.546). Column 2 shows the second-stage results, in which the PIT surcharge significantly increases in the pre-electoral year (1.01 per-capita Euros, corresponding to $3.5 \%$ of the sample mean), thereby strengthening the evidence for local revenues being affected by the political budget cycle. However, central to the issues at hand is the coefficient of neighbours' PIT, which is positive (0.49) and statistically significant at the $1 \%$ level. First- and second-stage results do not change when municipal controls are included (columns 3 and 4).

However, are more salient taxes affected by spatial interactions as well? I replicate the estimates by using the revenue from the ICI and from user fees \& charges as the dependent variables. Results are reported in Tables A2 and A3 of the Online Appendix. I find very weak evidence of a positive relationship between revenue from the property tax and that of neighbouring municipalities (columns 2 and 4 of Table A2). Conversely, the revenue from fees and charges appears to not be influenced by neighbours' choices, as the spatial coefficient turns out to be not statistically significant at the conventional levels (columns 2 and 4 of Table A3). However, these results must be read with some caution. First, as was already alluded to, rules on property tax setting changed frequently throughout the considered period, thus possibly undermining the validity of the results. Second, while the first stage is consistent with the incentive to reduce more visible taxes before elections, the use of the pre-electoral year of neighbouring municipalities as an instrument seems to perform poorly in terms of diagnostic tests in both cases. In fact, the Kleinbergen-Paap F statistics (11.637 and 11.697) are just above the ruleof-thumb of 10 in the case of the property tax (columns 1 and 3 of Table A2) and far below it in the case of user fees and charges ( 0.328 and 0.347 ; columns 1 and 3 of Table A3). 
Table 1: PIT surcharge and spatial interactions.

\begin{tabular}{|c|c|c|c|c|}
\hline Dependent variable & $\begin{array}{l}\text { Neighbours' PIT } \\
\text { (1) }\end{array}$ & $\begin{array}{l}\text { PIT } \\
\text { (2) }\end{array}$ & $\begin{array}{l}\text { Neighbours' PIT } \\
\text { (3) }\end{array}$ & $\begin{array}{l}\text { PIT } \\
\text { (4) }\end{array}$ \\
\hline Neighbours' PIT & & $\begin{array}{l}0.49^{\star \star \star} \\
(0.13)\end{array}$ & & $\begin{array}{l}0.51^{\star \star \star} \\
(0.13)\end{array}$ \\
\hline Neighbours one year before election & $\begin{array}{l}2.40^{\star \star \star} \\
(0.17)\end{array}$ & & $\begin{array}{l}2.41^{\star \star \star} \\
(0.18)\end{array}$ & \\
\hline One year before election & $\begin{array}{l}0.36^{\star \star \star} \\
(0.10)\end{array}$ & $\begin{array}{l}1.01^{\star \star \star} \\
(0.19)\end{array}$ & $\begin{array}{l}0.38^{\star \star \star} \\
(0.10)\end{array}$ & $\begin{array}{l}1.01^{\star \star \star} \\
(0.19)\end{array}$ \\
\hline Kleibergen-Paap F & 188.546 & 188.546 & 188.679 & 188.679 \\
\hline Year effects & Yes & Yes & Yes & Yes \\
\hline Municipal effects & Yes & Yes & Yes & Yes \\
\hline Municipal controls & No & No & Yes & Yes \\
\hline Observations & 61,292 & 61,292 & 61,292 & 61,292 \\
\hline R-squared & 0.6 & 0.32 & 0.60 & 0.32 \\
\hline Number of municipalities & 5572 & 5572 & 5572 & 5572 \\
\hline
\end{tabular}

Period of 2001-2011. Municipal control variables are population, age, child, 1/population, income, and commissioner. Neighbours' PIT is the average value across neighbours of the per capita revenue from the personal income tax surcharge. One year before election is a dummy variable equal to one 1 year before the election and zero otherwise. The variable Neighbours'spending is instrumented by using the following variable: neighbours one year before election, which is the average value across neighbours of the dummy variable one year before election. Robust standard errors clustered at the municipal level are shown in parentheses. Significance at the $10 \%$ level is represented by *, at the $5 \%$ level by **, and at the $1 \%$ level by ***.

These findings, obtained by employing a genuine external instrument, indicate the existence of a positive horizontal interdependence in tax collection between Italian municipalities that also depends on the salience of the tax instrument. ${ }^{13}$ Along these lines, while decisions on more visible and unpopular taxes appear to be weakly or even not affected by spatial effects, choices regarding less-salient fiscal tools, such as the PIT surcharge, are spatially correlated. In particular, I find that a one-euro increase in the average PIT revenue of neighbours generates, ceteris paribus, an increase of 0.49 Euro in the PIT revenue of municipality $i$. In practice, this reveals that the collection of non-salient taxes is a strategic complement. ${ }^{14}$

13 To assess the validity of the previous results, I perform a set of robustness checks. These checks are intended to address possible issues related to the validity of the instruments, which could bias the baseline estimates. To begin with, I use a different definition of the political budget cycle as an external instrument. After controlling for municipal and year fixed effects, I test for the potential presence of remaining sources of bias by performing balancing regressions, in the spirit of the test conducted by Pei et al. (2018). Finally, I conduct a battery of falsification tests. All of these checks are reported in the Online Appendix.

14 Similar results have been obtained by Bordingon et al. (2003), who relied on the traditional spatial econometric approach. 
To dig deeper into these results, I investigate whether spatial interactions differ according to the status-first or second term of office-of the mayor. Hence, I split the sample in two according to mayors in their first or second mandate. In relation to the yardstick competition hypothesis, municipalities guided by mayors facing a term limit are expected to be less concerned about competing with their own neighbours.

According to the second-stage results (column 2 and column 4 of Table 2), the coefficient accounting for spatial interactions in municipalities governed by firstterm mayors is found to be positive (0.66) and statistically significant at the $1 \%$ level, while the same coefficient turns out to be statistically indistinguishable from zero in the sample of municipalities led by mayors in their second term of office. Strikingly, what emerges is that spatial interactions only hold in municipalities governed by first-term mayors.

Table 2: PIT surcharge, spatial interactions, and mayoral term limits.

\begin{tabular}{|c|c|c|c|c|}
\hline \multirow[t]{2}{*}{ Dependent variable } & \multicolumn{2}{|l|}{ First-term mayors } & \multicolumn{2}{|c|}{ Second-term mayors } \\
\hline & $\begin{array}{l}\text { Neighbours' PIT } \\
\text { (1) }\end{array}$ & $\begin{array}{l}\text { PIT } \\
\text { (2) }\end{array}$ & $\begin{array}{l}\text { Neighbours' PIT } \\
\text { (3) }\end{array}$ & $\begin{array}{l}\text { PIT } \\
\text { (4) }\end{array}$ \\
\hline Neighbours' PIT & & $\begin{array}{l}0.66^{\star \star \star} \\
(0.16)\end{array}$ & & $\begin{array}{l}0.42 \\
(0.33)\end{array}$ \\
\hline Neighbours one year before election & $\begin{array}{l}2.70^{\star \star \star} \\
(0.25)\end{array}$ & & $\begin{array}{l}1.92^{\star \star \star} \\
(0.34)\end{array}$ & \\
\hline One year before election & $\begin{array}{l}0.53^{\star \star \star} \\
(0.13)\end{array}$ & $\begin{array}{l}0.55^{\star \star} \\
(0.27)\end{array}$ & $\begin{array}{l}0.21 \\
(0.19)\end{array}$ & $\begin{array}{l}1.27^{\star \star \star} \\
(0.37)\end{array}$ \\
\hline Kleibergen-Paap F & 116.359 & 116.359 & 31.400 & 31.400 \\
\hline Year effects & Yes & Yes & Yes & Yes \\
\hline Municipal effects & Yes & Yes & Yes & Yes \\
\hline Municipal controls & Yes & Yes & Yes & Yes \\
\hline Observations & 37,958 & 37,958 & 23,095 & 23,095 \\
\hline R-squared & 0.58 & 0.28 & 0.62 & 0.32 \\
\hline Number of municipalities & 5572 & 5572 & 5572 & 5572 \\
\hline
\end{tabular}

Period of 2001-2011. Municipal control variables are population, age, child, 1/population, income, and commissioner. Neighbours' PIT is the average value across neighbours of the per capita revenue from the personal income tax surcharge. One year before election is a dummy variable equal to one 1 year before the election and zero otherwise. The variable Neighbours' spending is instrumented by using the following variable: neighbours one year before election, which is the average value across neighbours of the dummy variable one year before election. Robust standard errors clustered at the municipal level are shown in parentheses. Significance at the $10 \%$ level is represented by *, at the $5 \%$ level by **, and at the $1 \%$ level by $* \star \star$. 


\section{Conclusion}

While many of the existing studies on spatial interactions are based on the 'standard' spatial econometric approach, which uses internal instruments to deal with the endogeneity of the neighbouring dependent variable, this paper exploits a purely external instrument. The results show that fiscal tools are affected by political manipulation but that the sign depends on the salience of the taxes. While the revenue of more visible and salient tax instruments, such as the property tax and user fees and charges, significantly decreases just before elections, the collection of the personal income tax surcharge (PIT) - which is not a very transparent tax tool-is found to be larger in pre-electoral years as compared to other years of the term. Then, I used this feature to induce exogenous variation in neighbouring municipalities' per capita revenue from these taxes.

The results point to the existence of tax mimicking between local governments in Italy, but only for less-transparent taxes, with this behaviour being more marked for non-binding term-limited mayors: a finding consistent with the yardstick competition hypothesis. What all these findings suggest is that tax competition, salience, and electoral incentives shape fiscal decisions taken at the local level.

Acknowledgements: I thank the editor Hendrik Schmitz, and one anonymous referee for suggestions that improved the paper significantly. The scientific output expressed does not imply a policy position of the European Commission. Neither the European Commission nor any person acting on behalf of the Commission is responsible for the use which might be made of this publication.

\section{References}

Agrawal, D. R. 2015. “The Tax Gradient: Spatial Aspects of Fiscal Competition.” American Economic Journal: Economic Policy 7: 1-29.

Allers, M. A., and J. P. Elhrost. 2005. "Tax Mimicking and Yardstick Competition Among Local Governments in the Netherlands." International Tax and Public Finance 12: 493-513.

Baskaran, T. 2014. "Identifying Local Tax Mimicking with Administrative Borders and Policy Reform." Journal of Public Economics 118: 41-51.

Baskaran, T. 2020. "Fiscal Interactions in the Short and the Long Run: Evidence from German Reunification." Journal of Economic Geography 20: 711-32.

Bocci, C., C. Ferretti, and P. Lattarulo. 2019. "Spatial Interactions in Property Tax Policies Among Italian Municipalities." Papers in Regional Science 98: 371-91.

Bordignon, M., F. Cerniglia, and F. Revelli. 2003. "In Search of Yardstick Competition: A Spatial Analysis of Italian Municipality Property Tax Setting.” Journal of Urban Economics 54: 199-217. 
Bordignon, M., V. Grembi, and S. Piazza. 2017. "Who Do You Blame in Local Finance? An Analysis of Municipal Financing in Italy." European Journal of Political Economy 49: 146-63.

Bracco, E. 2018. “A Fine Collection: The Political Budget Cycle of Traffic Enforcement.” Economics Letters 164: 117-20.

Bracco, E., F. Porcelli, and M. Redoano. 2019. "Political Competition, Tax Salience and Accountability. Theory and Evidence from Italy." European Journal of Political Economy 58: 138-63.

Burge, G. S., and C. L. Rogers. 2018. "Do State Sales Taxes Crowd Out Local Option Sales Taxes?" The B.E. Journal of Economic Analysis \& Policy 18 (3): 20180003.

Case, A. C., J. R. J. Hines, and H. S. Rosen. 1993. "Budget Spillovers and Fiscal Policy Interdependence. Evidence from the States." Journal of Public Economics 52: 285-307.

Ferraresi, M., U. Galamrini, L. Rizzo, and A. Zanardi. 2019. "Switch Towards Tax Centralization in Italy: A Wake Up for the Local Political Budget Cycle.” International Tax and Public Finance 26: 872-98.

Ferraresi, M. 2020. "Political Cycles, Spatial Interactions, and Yardstick Competition: Evidence from Italian Cities." Journal of Economic Geography 20: 1093-115.

Gibbons, S., and H. G. Overman. 2012. "Mostly Pointless Spatial Econometrics?” Journal of Regional Science 52: 172-91.

Isen, A. 2014. "Do local Government Fiscal Spillovers Exist? Evidence from Counties, Municipalities, and School Districts." Journal of Public Economics 110: 57-73.

Lyytikäinen, T. 2012. "Tax Competition Among Local Governments: Evidence from a Property Tax Reform in Finland." Journal of Public Economics 96: 584-95.

Padovano, F., and I. Petrarca. 2014. "Are the Responsibility and Yardstick Competition Hypotheses Mutually Consistent?” European Journal of Political Economy 34: 459-77.

Parchet, R. 2019. “Are Local Tax Rates Strategic Complements or Strategic Substitutes?” American Economic Journal: Economic Policy 11 (2): 189-224.

Pei, Z., J.-S. Pischke, and H. Schwandt. 2018. "Poorly Measured Confounders Are More Useful on the Left than on the Right." Journal of Business \& Economic Statistics 37: 205-16.

Repetto, L. 2018. "Political Budget Cycles with Informed Voters: Evidence from Italy." The Economic Journal 128: 3320-53.

Revelli, F. 2002. "Testing the Tax Mimicking Versus Expenditure Spillover Hypotheses Using English Data." Applied Economics 34: 1723-31.

Revelli, F. 2003. "Reaction or Interaction? Spatial Process Identification in Multi-Tiered Government Structures." Journal of Urban Economics 53: 29-53.

Sjahrir, B. S., K. Krisztina, and G. G. Schulze. 2013. "Political Budget Cycles in Indonesia at the District Level.” Economics Letters 120 (2): 342-5.

Supplementary Material: The online version of this article offers supplementary material (https:// doi.org/10.1515/bejeap-2020-0380). 